\title{
The propensity to continue service internationalization : a model of planned behavior
}

Citation for published version (APA):

Pauwels, P. F. J., Patterson, P. G., de Ruyter, J. C., \& Wetzels, M. G. M. (2003). The propensity to continue service internationalization : a model of planned behavior. METEOR, Maastricht University School of Business and Economics. METEOR Research Memorandum No. 034 https://doi.org/10.26481/umamet.2003034

Document status and date:

Published: 01/01/2003

DOI:

10.26481/umamet.2003034

Document Version:

Publisher's PDF, also known as Version of record

\section{Please check the document version of this publication:}

- A submitted manuscript is the version of the article upon submission and before peer-review. There can be important differences between the submitted version and the official published version of record.

People interested in the research are advised to contact the author for the final version of the publication, or visit the DOI to the publisher's website.

- The final author version and the galley proof are versions of the publication after peer review.

- The final published version features the final layout of the paper including the volume, issue and page numbers.

Link to publication

\footnotetext{
General rights rights.

- You may freely distribute the URL identifying the publication in the public portal. please follow below link for the End User Agreement:

www.umlib.nl/taverne-license

Take down policy

If you believe that this document breaches copyright please contact us at:

repository@maastrichtuniversity.nl

providing details and we will investigate your claim.
}

Copyright and moral rights for the publications made accessible in the public portal are retained by the authors and/or other copyright owners and it is a condition of accessing publications that users recognise and abide by the legal requirements associated with these

- Users may download and print one copy of any publication from the public portal for the purpose of private study or research.

- You may not further distribute the material or use it for any profit-making activity or commercial gain

If the publication is distributed under the terms of Article $25 \mathrm{fa}$ of the Dutch Copyright Act, indicated by the "Taverne" license above, 


\section{The Propensity to Continue Service Internationalization A Model of PlanNed BehaVior}

Pieter Pauwels*

Universiteit Maastricht, The Netherlands

Paul G. Patterson

University of New South Wales, Australia

Ko de Ruyter

Universiteit Maastricht, The Netherlands

Martin Wetzels

Technische Universiteit Eindhoven, The Netherlands

Keywords: Service internationalization, attitudinal commitment, planned behavior, partial least squares

\footnotetext{
* Corresponding author: Piet Pauwels, Universiteit Maastricht, Faculty of Economics and Business Administration, Department of Marketing and Marketing Research, PO BOX 616, 6200 MD Maastricht, The Netherlands, Phone: +3143.3883774, Fax: +31-43.3884918, E-mail: p.pauwels@mw.unimaas.nl
} 


\title{
The Propensity to Continue Service Internationalization A Model of Planned Behavior
}

\begin{abstract}
The present study investigates the propensity to continue internationalization by experienced international service providers. Enhancing the cognitive-behavioral root of internationalization process theory (Johanson and Vahlne 1977; 1990), this paper builds upon Ajzen's (1991) theory of planned behavior. Consistent with the latter theory, the propensity to continue service internationalization is modelled as behavioral intention that results from (1) an overall attitude towards internationalization, (2) structural and strategic behavioral norms, and (3) inhibiting factors that exert behavioral control upon propensity. Using partial least squares analysis, a propensity model is tested on a sample of 193 international service providers. The results suggest that our model explicates and enhances the cognitive/affective character of internationalization process theory.
\end{abstract}

\section{Introduction}

Service internationalization is a complex process. In industries such as banking, retail, logistics, business consulting, engineering and project management numerous examples are known of firms that recently experienced major complications in their internationalization strategy, especially due to the inherent characterstics of their very market offering - intangible services. Both empirical and theoretical work (e.g., Erramilli 1990; Li 1994; Patterson and Cicic 1995; O’Farrell, Wood and Zheng 1996; Björkman and Kock 1997; Majkgård and Sharma 1998; Capar and Kotabe 2003) have uncovered particular complexities of service internationalization. These studies illustrate that the distinguishing attributes of services, especially intangibility, variability and, similtaneous production and consumption (Zeithaml 
and Bitner 1996), impose unique difficulties during as well as beyond the start of an internationalization process (Buckley, Pass and Prescott 1991; Knight 1999; Lovelock and Yip 1996; McLaughlin and Fitzsimmons 1996). Services cannot be easily displayed or communicated to potential overseas clients, and they cannot be directly exported in the way physical goods can because production and consumption cannot be separated. As Nicaloud (1989) points out "service marketers do not enjoy the same opportunities for learning from gradual experience as goods firms, via indirect or casual exporting. The international marketer of services has got no choice but to deal directly with the foreign customer" (p.58). Thus service firms are forced to choose from a reduced set of entry modes when internationalizing. Finally, since many services are high contact - that is key personnel provide the expertise (project management, civil or mining engineer) they are often required to be on foreign soil from day one.

Nevertheless, more service enterprises than ever before are seeking opportunities abroad and compete on an international or even global scale. Dominant drivers such as the deregulation of international trade in services, globalization of industries, and advances in information and communication technology among others, have significantly intensified cross-border trade of services. Today, services officially represent more than $20 \%$ of world trade and are the fastest growing sector of world trade for the last two decades (World Trade Organization 2001). Furthermore, in many manufactured goods markets, the service component of market offerings is responsible for a major and increasing part of the total value (Brown et al. 2001). This 'hidden service sector' (Grönroos 1990) offers a leverage for many firms' differentiation potential. It is fair to state that cross-border service delivery has become a mature and fully integrated activity in many of today's multinational enterprises. 
With respect to service internationalization, research is lagging behind. To date, academic interest has primarly focused on the (pre-) start-up phase of service internationalization (Knight 1999; Lommelen, Matthyssens and Pauwels 2001). Some of the most popular themes are: (1) internationalization motives (Winsted and Patterson 1998), (2) country/market selection (Kundu and Contractor 1999), (3) initial entry mode choice (Erramilli 1992; Ekeledo and Sivakumar 1998), and (4) typologies of international services (Patterson and Cicic 1995). With the increasing prominence and integration of international services in the world economy, the time is right for investigating the process of service internationization beyond its start-up phase (Capar and Kotabe 2003).

The present study focuses on ongoing service internationalization. In particular, we investigate the antecedents of a service firm's propensity to continue internationalization. Relying upon the Theory of Planned Behavior (Ajzen 1991), we model propensity as a function of salient normative, affective and control beliefs. To accommodate this perspective in a more traditional behavioral perspective on internationalization, we develop the attitudinal component of the Uppsala Model (Johanson and Vahlne 1977; 1990). Attitudinal commitment serves as a pivotal construct to embed our model of behavioral intention into a broader stream of behavioral research on the internationalization of the firm.

The remainder of this paper goes as follows. First, we shortly review the literature on service firms' propensity to continue internationalization. In the next section, we present internationalization process theory and more in particular the so-called Uppsala Model as a theoretical point of reference and develop the attitudinal component of the Uppsala Model in section four. In section five, we present the Theory of Planned Behavior as a point of departure for the empirical study. In section six, we translate the latter theory to model the 
propensity to continue service internationalization and present accompanying hypotheses. The next section presents the design of the empirical study. Section seven discusses the analytical findings. The paper finishes with an interpretation of these findings, managerial implications, a discussion of the theoretical contribution and limitations, and some specific recommendations for future research.

\section{Propensity to continue internationalization}

To the best of our knowledge, only a very limited number of studies have investigated a firm's propensity to continue internationalization. These studies mainly focused on the impact of past performance on future commitment to internationalization. Illustrative is a study by Patterson, Cicic and Shoham (1997) that relies on the disconfirmation of expectations paradigm (Anderson 1973; Oliver 1980) to explain export satisfaction and intention. Testing their model on a sample of service firms, the authors indeed found that the subjective/relative performance measure is a stronger predictor of both satisfaction and intention than the objective/absolute performance measure. More recently, Lages and Montgomery (2001) investigated how foreign market development, competition, and satisfaction with past performance influence a firm's commitment to continue exporting. The study supports the idea that satisfaction with export performance is a prime antecedent of a firm's ongoing commitment to exporting. To develop a contingence perspective on the relationship between perceived performance, satisfaction and export intention, Lages and Montgomery (2001) suggest to accommodate moderating exogenous (e.g., competitive pressure) as well as endogenous variables (e.g., management commitment). 
Patterson, de Ruyter and Wetzels (1999) extend the Patterson et al. (1997) model to include external and internal export motives along satisfaction with previous export efforts and current export intensity as antecedents of intended future export commitment. Using factor analysis five export motives were distinguished: the attractiveness of export market incentives, management commitment, domestic push, client following and competitor following. While the overall power of the model turned out acceptable, only one of the five motivational factors - management commitment - significantly contributed to the explanation of future export intention. It is striking to observe that all non-significant motives in Patterson et al. (1999) are related to strategic considerations, which have been indicated in the extant literature as critical in the course of the internationalization process of a service firm (e.g., Blomstermo and Sharma 2003 for an overview). This may point at a high level of nonrationality in the cognitive processes that precede a firm's commitment to future international market commitment. The present study aims at the further development of the Patterson et al. (1997) model to include non- or less rational cognitive elements in the context of an ongoing internationalization process.

\section{Point of reference: internationalization process theory}

A dominant theoretical point of reference for the study of internationalization processes is the so-called Uppsala Model (Johanson and Vahlne 1977; 1990). Building upon a behavioral theory of the firm (Cyert and March 1963) and Penrose's (1959) theory of the growth of the firm, the basic logic of the Uppsala or U-Model is quite straightforward: The allocation of resources to foreign activities holds a certain risk and induces experiential learning (learningby-doing), which results in market-specific knowledge. The increased stock of marketspecific knowledge reduces the risk in this particular market and stimulates additional 
allocation of resources (Eriksson et al. 1997). Although initially developed to explain the internationalization of manufacturing firms, the logic of the U-Model holds for services firms where people (and their knowledge and skill base) are the key resources of the firm. Personnel who are required to deal with international clients on a face-to-face basis to 'manufacture' the service (e.g., engineer, management consultant) learn not only about the international process, but also about relational behaviors in a foreign environment.

Fundamentally, the U-Model relies upon four (implicit) assumptions. First, firms maximize the expected future rent of their resources by allocating these to markets where doing business is judged to be least risky (Anderson 1993). Second, risk is reduced only through increasing market-specific knowledge. Third, market-specific knowledge is acquired through experiential learning (Johanson and Vahlne 1977). Finally, experiential learning is assumed an efficient process. Internationalization processes would not embark and/or continue if experiential learning would be or would become an inefficient process. Because experiential learning is a time-consuming incremental process (Huber 1991), the internationalization process is expected to be an incremental process alike (Johanson and Vahlne 1977; 1990; Pedersen and Petersen 1998). In sum, given risk aversion, internationalization is incremental and solely driven by experiential learning (Johanson and Vahlne 1977; Pedersen and Petersen 1998; Forsgren 2002).

Since its conception in the mid 1970s, the impact of the U-Model on international business research has only increased, in both a product and a service context. To date, the UModel remains a popular theoretical - almost paradigmatic - point of reference for the study of (services) internationalization (e.g., Bell 1995; Coviello and Munro 1997; Kim 2003). Nevertheless, the U-Model has been challenged from both theoretical (e.g., Andersen 1993; 
Hadjikhani 1997; Björkman and Forsgren 2000) and empirical perspectives (e.g., Sullivan and Bauerschmidt 1990; Millington and Bayliss 1990). Its main problem seems to be the endogenous (i.e., non-discretionary) incremental character of the internationalization process. In terms of its founders: "Once it has started, [the internationalization process] will tend to proceed regardless of whether strategic decisions in that direction are made or not" (Johanson and Vahlne 1990: 12). Moreover, the popular normative 'stages' representation made the UModel even highly deterministic (Turnbull 1987). However, even without the straightjacket of an establishment chain, the U-Model apparently fails to explain leapfrogging, discontinuity, and withdrawal in the internationalization process (Benito and Welch 1997; Pedersen and Petersen 1998) nor does it cope with managerial discretion that goes beyond the optimization of the experiential learning process (Buckley 1996). With respect to the present study, these apparent shortcomings are critical and require further investigation.

Contemporary adepts of internationalization process theory argue that this apparent rigidness of the U-Model accrues from the narrow conceptualization of its fundamental building blocks. Therefore, all lenses are currently focused on the upgrading of the knowledge concept and on a better understanding of the underlying learning process (e.g., Eriksson et al. 1997; 2000; Forsgren 2002). This promising route is ongoing (Blomstermo and Sharma 2003). The alternative route enters the U-Model via market commitment and commitment decisions. Although this alternative route remains poorly explored to date, we judge it essential to exploit the truly behavioral character of the U-Model. A first step in this respect is the acknowledgement and further development of the attitudinal component of the U-Model. 


\section{Pivotal construct: attitudinal commitment}

In the original U-Model, market commitment is composed of two factors - the amount of resources committed and the degree of commitment. The amount of resources points at the economic factors allocated to a particular market. Market commitment increases when a firm allocates more inputs to manage and support foreign operations. The degree of commitment represents the difficulty of finding alternative uses for these resources (Johanson and Vahlne 1990; Andersen 1993). Hadjikhani (1997) extends this conceptualization. He argues that the amount of commitment points at the short term tangible (i.e., financial and institutional) forms of commitment, whereas the degree of commitment captures more the intangible long-term elements of commitment. Focusing on tangible and intangible commitment as separate constructs does not refute the U-Model's logic yet promises a more dynamic perspective on internationalization. For instance, it could help explaining market withdrawal (decreasing tangible commitment) as a decision of product/market portfolio optimization in the context of a progressing (increasing intangible commitment) internationalization process (Douglas and Craig 1996; Pauwels and Matthyssens 2003).

Hadjikhani's (1997) two-dimensional conceptualization of market commitment corresponds with a contemporary understanding of the construct that distinguishes between attitudinal commitment and behavioral commitment (Meyer and Allen 1991; Gundlach, Achrol and Mentzer 1995). Nevertheless, we argue that the attitudinal dimension of commitment in the original U-Model remains largely underdeveloped. This is problematic since the unmediated relation between market knowledge and behavioral market commitment in the original model is symptomatic of the endogenous incremental character of the UModel. 
The management literature has now commonly conceptualized attitudinal commitment as a cognitive-affective state composed of an affect, a continuance, and a normative dimension (Meyer and Allen 1991; Anderson and Weitz 1992; Gundlach et al. 1995; Skarmeas, Katsikeas and Schlegelmilch 2002). The affect dimension of commitment refers to the emotional attachment to a market. Firms with a strong affective commitment towards a particular market continue their commitment because they really want to be in that market. In a services context this also applies to the affect built up between individuals - i.e., individual service provider (e.g., consulting engineer) and the overseas client, and has been shown to enhance export performance ( $\mathrm{La}$ et al. 2002). The continuance dimension refers to an awareness of the costs associated with leaving the market. As such, this dimension comes closest to the degree of commitment as defined by Johanson and Vahlne (1977). Firms with a strong continuance commitment towards a particular market continue their commitment because they need to be/stay in that market. Normative commitment reflects a feeling of obligation to remain committed to that market. Firms with a strong normative commitment towards a particular market continue their commitment because they ought to be/stay in that market (Meyer and Allen 1991).

To integrate attitudinal commitment in the U-Model its relationship with behavioral commitment has to be made explicit. Following Meyer and Allen (1991) and Mowday, Porter and Steers (1982) we suggest an ongoing reciprocal influencing process. Actual behavior is instrumental to shaping attitudes, which, on their turn, act as inputs for decisions to deploy resources (i.e., behavioral commitment). As such, attitudinal commitment should be entered as a three-dimensional construct that mediates the relationship between market knowledge and market commitment in the U-Model. 
In sum, we suggest to explicitly adopt attitudinal commitment as a construct that mediates the relationship between market knowledge and (behavioral) market commitment. The explicit acknowledgment of an attitudinal construct paves the way for the accommodation and explanation of, among others, behavioral intention - or propensity within the logic of the U-Model. In this respect, we deliberately forgo the dominant logic that internationalization decisions are the rational response to market conditions and are made on the basis of objective information that is gathered systematically (Ellis and Pecotich 2001).

\section{Point of extension: the Theory of Planned Behavior}

When building upon attitudinal commitment to model and investigate a firm's propensity to continue internationalization, it is crucial to remain consistent with extant explanatory models of attitude and behavior. In this respect, Fishbein and Ajzen's (1975) Theory of Reasoned Action and Ajzen's (1988; 1991) Theory of Planned Behavior are most relevant.

As the predecessor of Ajzen's (1991) Theory of Planned Behavior, the Theory of Reasoned Action (TRA) (Fishbein and Ajzen 1975) proposes that behavior is determined by behavioral intention, which, in turn, is influenced by a person's attitudes and subjective norms (Ajzen and Fishbein 1980). According to TRA, the attitude towards a behavioral intention is determinent by a person's salient beliefs about the consequences of the behavior multiplied by the evaluation of the consequences. This attitude equation represents an information processing view of how attitudes are formed and change with the influence of external stimuli on the individual's belief structure (Ajzen and Fishbein 1980). The more an individual beliefs that performing the behavior will lead to desired outcomes, the more favorable the person's 
attitude will be. As a second antecedent of behavioral intention, subjective norms are determined by a person's normative beliefs, which are expectations of certain reference groups, and the person's motivation to comply with these expectations (Fishbein and Ajzen 1975). Both attitudes and subjective norms are important to explain behavioral intention. Research using TRA has proved successful across a number of disciplines (Sheppard, Hartwick and Warshaw 1988) and was "designed to explain virtually any human behavior" (Ajzen and Fishbein 1980: 4).

Compared to TRA, Ajzen's $(1988 ; 1991)$ Theory of Planned Behavior (TPB) adds perceived behavioral control as a third antecedent of behavioral intention. Apart from a personal (attitude) and a social (subjective norms) antecendent, percieved behavioral control captures the person's "perception of ease or difficulty of performing the behavior of interest" (Ajzen 1991: 183). According to TPB, behavioral intention is strongly influenced by a person's confidence or belief in his/her ability to perform a behavior (Bandura 1991). At the most basic level of explanation, TPB postulates that behavioral intention is a function of salient behavioral, normative and control beliefs relevant to this particular behavior.

\section{A model of the propensity to continue service internationization}

Building upon Ajzen's (1991) TPB, the propensity to continue service internationalization is conceived as behavioral intention that results from three antecedents: (1) the firm's overall attitude towards internationalization, (2) the firm's current intensity of internationalization, and (3) the percieved fit between internationalization and the firm's corporate strategy. The effect of these antecedents on the firm's propensity is moderated by a perceived degree of 
self-efficiency of internationalization (Figure 1). Next, we discuss the role of each of these constructs.

Fig. 1: The propensity to continue internationalization: A partially mediated model of planned behavior

A firm's overall attitude towards internationalization is considered as a crucial antecedent to the propensity to continue internationalization. This attitude captures the firm's subjective desire to continue internationalization and develops from salient beliefs: outcome beliefs and normative beliefs (Ajzen and Fishbein 1975). Building upon Patterson et al. (1997), it is expected that disconfirmation of expectations of the outcomes of internationalization is a prime antecedent of a firm's attitude and, eventually, of its intention to continue internationalization. Active international service firms should have at least implicit expectations about what benefits internationalization might bring. These expectations serve as a benchmark against which subsequent performance is compared or disconfirmed. Positive (negative) disconfirmation occurs when actual performance is perceived as falling short of (exceeding) expectations. According to Anderson (1973), Oliver (1980) and Oliver and DeSarbo (1988) disconfirmation feeds overall attitude towards a particular behavior. This approach has been applied and supported in earlier studies on export satisfaction and export propensity (Patterson et al. 1999; Wang and Olson 2002). Hence, we propose:

$\mathrm{H}_{1}$ : The propensity to continue internationalization is expected to be positively related to the overall attitude towards internationalization. 
$\mathrm{H}_{2 \mathrm{a}}$ : The overall attitude towards internationalization is expected to be positively related to the positive disconfirmation of expectations about past internationalization behavior.

The intensity of internationalization is proposed as a second antecedent of attitude. Current intensity is adopted as a proxy for the degree of institutionalization of a firm's internationalization process (Selznick 1957; Boeker 1989; Sullivan 1994). In the model, the degree of institutionalization of internationalization feeds normative beliefs, which are expected to have significant impact on the firm's attitude towards continuing internationalization. Whereas internationalization intensity captures the structural component of the normative antecedent, strategic fit, a third antecedent of attitude, confines the strategic component of the normative antecedent. The perceived fit between the strategic option to continue internationalization on the one hand and the firm's corporate strategy and goals on the other represent normative beliefs that influence the attitude towards internationalization (Nelson and Winter 1982; Boeker 1989; Hamel and Prahalad 1989). Accordingly, we propose:

$\mathrm{H}_{2 \mathrm{~b}}$ : The overall attitude towards internationalization is expected to be positively related to the intensity of internationalization.

$\mathrm{H}_{2 \mathrm{c}}$ : The overall attitude towards internationalization is expected to be positively related to the perceived strategic fit between internationalization and the corporate strategy.

In line with Fishbein and Ajzen (1975), the attitudinal antecedent is complemented with a subjective norm that directly affects a firm's propensity to a certain behavior. Apart 
from its expected impact on attitude, the institutionalization of past behavior is expected to have a direct impact on the propensity to continue internationalization. This direct relation is supported by theories of creeping and escalating commitment (e.g., Kelly and Amburgey 1991; Ross and Staw 1993) and captures the acceptability of this behavior given current organizational routines, procedures and structures. It is expected that the mere intensity of the firm's current international program contributes to a subjective norm that influences a firm's intention to continue internationalization in the same way and intensity as before. Parallel to structural inertia, strategic fit represents strategic inertia and complements the normative effect on intended behavior.

$\mathrm{H}_{3}$ : The propensity to continue service internationalization is expected to be positively related to the current intensity of internationalization.

$\mathrm{H}_{4}$ : The propensity to continue service internationalization is expected to be positively related to the perceived strategic fit between internationalization and the corporate strategy.

Consequently, the firm's current internationalization intensity and the perceived strategic fit play a double role in the model. First, they act as (proxies) of belief structures that shape the attitude towards internationalization. Second, the two constructs captures the subjective organizational and behavioral norms to continue internationalization. Davis, Bagozzi and Warshaw (1989) among others illustrate that a single antecedent can play more than one role in a model of behavioral intention. In this perspective, it is theoretically relevant to test the explanatory power of the fully mediated model (only indirect effects of normative constructs) in comparison to the power of a partially mediated model (both direct and indirect effects of normative constructs). In this respect, we hypothesize: 
$\mathrm{H}_{5}$ : A partially mediated model outperformes a fully mediated model in the explanation of the propensity to continue internationalization.

To accommodate behavioral control as suggested by Ajzen (1991), we measure a manager's perception of both internal and market inhibitors. This way, we capture a firm's perception of the feasibility of internationalization. If the decision-maker perceives high barriers within the firm (e.g., limited resources or a lack of relevant capabilities) or in the foreign market (e.g., level of competition) the intention to continue internationalization is expected to be attenuated. Managers may claim that they are very much in favor of internationalization (attitude), yet forgo the opportunity to commit resources to this strategic option because they perceive the option as unfeasible. In contrast to Ajzen (1991) who proposes behavioral control as a mediator, we model internal and market inhibitors as moderators that impact upon the relationship between attitude and the two normative constructs at the one hand, and the firm's propensity on the other. This choice is supported by Sheppard et al. (1988). Hence, we propose:

$\mathrm{H}_{6 \mathrm{a}, \mathrm{b}, \mathrm{c}}$ : The higher (lower) the degree of perceived internal and market inhibitors, the weaker (stronger) the direct impact of (a) intensity, (b) attitude, and (c) percieved strategic fit on the propensity to continue internationalization.

To complete the model in a service context, we acknowledge the moderating effect of personal interaction with foreign customers during service delivery on the development of an attitude. In line with perception-knowledge-belief theory (Dretske 2000), it is expected that a higher degree of personal interaction during service delivery enhances the relationship 
between salient beliefs and the emerging attitude. These interactions provide a person with a higher perceived sense of expertness, which inflates the perceived truthfullness of his or her own beliefs. Accordingly, we propose:

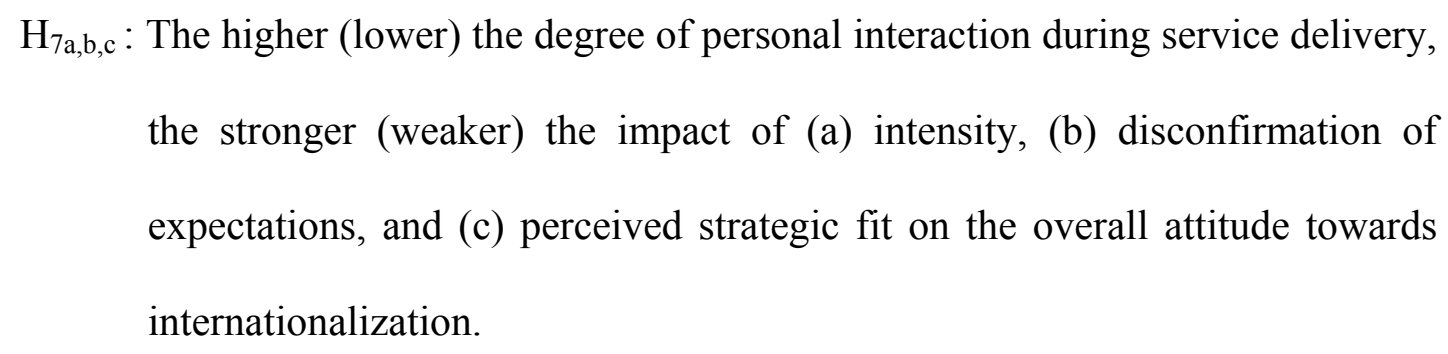

\section{Research design}

A three-stage research design was employed to test the hypotheses related to the partially mediated model (Figure 1). The first stage consisted of 15 semi-structured in-depth interviews with service firms involved in international operations. The purpose of this qualitative phase was twofold. First, we aimed at understanding how the antecedents of a firm's propensity to continue internationalization were interrelated in practice. Second, the interviews provided a glimpse on the (implicit) decision-making process that underlies this apparently incomplete volitional model. While this knowledge enhanced the interpretation of the analytical results, a discussion of the process elements of this model goes beyond the ambition of this paper.

Stage two involved a cross-sectional survey of service organizations. Pre-tested, selfadministered questionnaires were mailed to a non-probability sample of 1264 organizations in Australia. The Australian service sectors provide an ideal context for a study such as this. It has produced thriving service economies (especially professional services such as engineering, business consultancy, legal and medical firms). Moreover, this sector has been 
especially aggressive in capitalizing on overseas market opportunities, especially in the AsiaPacific region. The questionnaire was directed to the senior executive officer responsible for the organization's internationalization efforts or, in case no such officer existed, to the senior marketing person. After one follow-up reminder letter and the incentive of receiving an executive summary of the findings, 347 usable questionnaires were returned of which 193 were involved in service export. A further 183 were returned due to incorrect address or incomplete information and 67 reported they were only involved in marketing goods. After excluding these, the net response rate of the survey is $34.2 \%$. An analysis of those questionnaires returned from a second wave mailing were compared with the first wave, as recommended by Armstrong and Overton (1977), and revealed no statistically significant differences $(\alpha=0.05)$ on a number of key questions.

Stage three of the analysis was organized after the statistical analysis of the survey. Four experienced top managers of four internationally operating service firms were asked to comment extensively on the outcomes of the survey. Alternative interpretations of the empirical results were discussed with these managers. This stage significantly helped upgrading the managerial logic of the discussion section as well as the identification of remaining study topics.

\subsection{Measures}

Table 1 gives an overview of the indicators and scales used in the questionnaire. Except for disconfirmation of expectations, all measures had to be operationalized for the purpose of this study. To operationalize the former we followed Patterson, Cicic and Shoham (1997) and Wang and Olson (2002). 
Except for internationalization intensity, which is an emergent construct with two formative indicators, the remaining non-moderating latent variables are measured using multiple reflective indicators. To assess the reliability of the measures we calculated the composite scale reliability (Werts, Linn and Jöreskog 1974; Fornell and Larcker 1981; Chin 1998) and the average variance extracted (Fornell and Larcker 1981; Chin 1998). As far as composite scale reliability was concerned, all measures exceeded a value of 0.90 . Moreover, the square root of the average variance extracted exceeded the intercorrelations of the construct with the other constructs in the model indicating discriminant validity in the model (Barclay, Higgins and Thompson 1995; Chin 1998). Table 2 summarizes the reliability analysis.

Table 2: Composite reliability and intercorrelations of latent variables

\subsection{Data Analysis}

To analyze the survey data we used a Partial Least Squares (PLS) approach as implemented in PLS-Graph 3.0 (Chin 2001) to estimate both the measurement and structural parameters in our structural equation model (Lohmöller 1989; Barclay et al. 1995; Chin 1998; Hulland 1999). Given the particular design and context of this study, several arguments support the use of PLS. First, as opposed to the covariance- or factor-based approach to structural equation modeling implemented for example in LISREL, PLS is component-based. Therefore, PLS does not require multivariate normal data, places minimum requirements on measurement levels, and is more suitable for relatively small samples (Chin 1998). Second, Jöreskog and Wold (1982) argue in favor of PLS when the research setting is relatively 
complex and theoretical information is limited. As such, PLS is recommended over LISREL when the emphasis of the study is more on theory development. Third, PLS enables to assess individual item reliability, convergent validity of the measures associated with individual constructs, as well as discriminant validity (Duxbury and Higgins 1991; Barclay et al. 1995; Hulland 1999). A minor yet interesting advantage of PLS is that its results can be interpreted easily since the path coefficients in a PLS structural model are standardized regression coefficients and the item loadings in the measurement model can be read as factor loadings. An acknowledged disadvantage of PLS is the lack of an appropriate goodness-of-fit measure.

To test for the moderator effects specified in the conceptual model we used a method analogous to moderated regression analysis (Duxbury and Higgins 1991). We established two groups for each moderator based on a median split. PLS was subsequently used to obtain parameter estimates and bootstrapping to provide the standard errors of the estimates and the accompanying $t$ statistics. The path coefficients for the two groups are tested for significance using an independent samples $t$ test (Duxbury and Higgins 1991; Chin 2000). A conservative value of $\alpha=0.01$ was used for the significance level.

\section{Analytical results and discussion}

This section presents and discusses the analytical results in three steps. First, we present the outcomes of the PLS analysis of the partially moderated model. Second, we compare this partially mediated model to a fully mediated model. Finally, we discuss the results of moderator analysis. 
Figure 2 presents the PLS parameter estimates of the partially mediated model. All relationships are significant at $\alpha=0.01$ except for the relationship between intensity and propensity which is weaker yet significant at $\alpha=0.05$. The findings show that the propensity to continue internationalization relates significantly to the overall attitude towards internationalization $\left(\mathrm{H}_{1}\right.$ supported), to the intensity of internationalization $\left(\mathrm{H}_{3}\right.$ supported), and to the perceived strategic fit between internationalization and the corporate strategy $\left(\mathrm{H}_{4}\right.$ supported). The overall attitude, on its turn, significantly relates to salient beliefs on the disconfirmation of performance expectations $\left(\mathrm{H}_{2 \mathrm{a}}\right.$ supported), to the current intensity of internationalization, i.e., the perceived degree of institutionalization $\left(\mathrm{H}_{2 b}\right.$ supported), and to salient beliefs about the congruence between internationalization and the corporate strategy $\left(\mathrm{H}_{2 \mathrm{c}}\right.$ supported).

Fig. 2: PLS Parameters Estimates of Partially Mediated Model

In general, the model shows a more than acceptable variance explained for attitude $\left(\mathrm{R}^{2}=0.54\right)$ as well as for internationalization propensity $\left(\mathrm{R}^{2}=0.42\right)$. As a point of reference, Sheppard et al. (1988) indicated that models of reasoned action explain between 20 and 30\% of the variance in behavioral intention. To test the very volitional character of our model, as postulated in hypothesis 5 , we compare the partially mediated model with the nested fully mediated model. In the latter model, we assume that the propensity to continue internationalization is a pure volitional process. Practically, this means that propensity is only explained by attitude and no direct relations between the normative antecedents (i.e., intensity and strategic fit) and propensity are postulated. In support of hypothesis 5 , the $\mathrm{R}^{2}$ of propensity in the fully mediated model is significantly lower than the $\mathrm{R}^{2}$ of propensity in the 
partially mediated model $\left(\mathrm{R}_{\text {partial }}^{2}=0.42 \mathrm{vs.} \mathrm{R}_{\text {full }}=0.34 ; \mathrm{F}_{2,189}=13.03, \mathrm{p}<0.001\right)$. This supports the validity of a semi-volitional or partially mediated model as put forward in hypothesis 5 .

Table 3 indicates the standardized path coefficients of the moderators as presented in Figure 1. The moderator effects on the relationship between attitude and propensity $(\mathrm{ATT} \rightarrow \mathrm{PROP})$ are significant and attenuate or strengthen as expected. Compared to the nonmoderated model, the relationship between attitude and propensity becomes significantly stronger in case of low internal inhibitors $\left(\beta_{\mathrm{IL}}=0.48\right.$ vs. $\left.\beta=0.31 ; \mathrm{p}<0.01\right)$ and significantly weaker in case of high internal inhibitors $\left(\beta_{\mathrm{IH}}=0.20\right.$ vs. $\left.\beta=0.31 ; \mathrm{p}<0.01\right)$. The same counts for the effect of market inhibitors on the relationship between attitude and propensity. These results support hypothesis 6a, which postulated that the higher (lower) the degree of perceived internal and market inhibitors, the weaker (stronger) the direct impact of intensity on the propensity to continue internationalization. As indicated in Table 3, the moderator effects on the relationship between intensity and propensity (INT $\rightarrow$ PROP) are insignificant for low internal and high market inhibitors and are opposite to the direction proposed in hypothesis $6 \mathrm{~b}$ in the case of internal inhibitors, albeit insignificantly. As such, these findings do not support hypothesis $6 \mathrm{~b}$ which stated that higher (lower) internal and external inhibitors attenuate (strengthen) the impact of intensity on propensity.

Table 3: Results of moderator analysis

The moderator effects on the relationship between strategic fit and propensity (FIT $\rightarrow$ PROP) are all significant, but opposite to the expected direction. Contrary to what is stated in hypothesis $6 \mathrm{c}$, higher internal and market inhibitors seem to strengthen the 
relationship between strategic fit and propensity. Therefore, hypothesis $6 \mathrm{c}$ cannot be supported. Although these findings were not expected, they are possibly explainable as a respondent in one of the additional case study comments: "As long as we can play our own game, $[\ldots]$ the more barriers we see, the more we go for it. If we can cross the river in our way, we might be alone on the other side." This interpretation concurs with Hamel and Prahalad (1989) who argued that strategic fit materializes more strongly in case of obstruction. Nevertheless, more analysis is required to investigate these findings.

Finally, the lower part of Table 3 presents the results of the moderator effect of the degree of personal international with customers during service delivery (hypothesis 7). Concerning the impact on the relationships between intensity and attitude (INT $\rightarrow$ ATT) and between disconfirmation and attitude (DIS $\rightarrow$ ATT), the results are significant and support hypotheses $7 \mathrm{a}$ and $7 \mathrm{~b}$ respectively. With respect to the impact on the relationship between strategic fit and attitude (FIT $\rightarrow$ ATT), Table 3 shows significant yet unexpected results. Contrary to what was postulated in hypothesis 7c, a higher (lower) degree of personal interaction attenuates (strengthens) the impact of strategic fit on attitude. Therefore, hypothesis $7 \mathrm{c}$ cannot be supported. More interaction with the local market results in more feeling with the internationalization process and, as a consequence, in a stronger belief that the subjective interpretation of a limited number of data may steer future internationalization. However, less personal interaction during service delivery seems to strengthen the impact of strategic fit on attitude, a finding that may be explained in line with the myopic momentum of strategic fit as discussed above.

Although some of the hypotheses related to the moderating variables cannot be supported, in general the moderators have a significant impact on the partially mediated 
model. The significant impact of the inhibitors supports the idea that the behavioral control part of the Theory of Planned Behavior (Ajzen 1991) plays a significant part in the explanation of the propensity to continue internationalization. The moderating impact of the degree of personal interaction supports the relevance of making the model contingent upon a services context.

\section{Conclusion}

The aim of this study was to investigate the antecendents of a firm's propensity to continue service internationalization. Building upon the pivotal role of attitudinal commitment, a model of behavioral intention was nested in the established internationalization process theory. This model was developed on the basis of Ajzen's (1991) Theory of Planned Behavior and tested on a sample of 193 Austalian international service providers. Our findings show that the propensity to continue internationalization depends on overall attitudes, behavioral norms, and behavioral control factors. This implies that the internationalization process of the firm is neither the result of a rational decision-making process, as implicitly assumed in some earlier work on internationalization (e.g., Young et al. 1989), nor is it the outcome of a purely evolutionary process as assumed in the Uppsala Model (Johanson and Vahlne 1990).

To the extent that ongoing internationalization is the result of managerial discretion, the findings support the idea that it is not build upon a rational decision-making process, which relies upon exhaustive information sources. To the contrary, it seems that the volitional character of internationalization emerges from simple heuristics and compensatory interactions among belief structures, which aim at satisficing (not optimizing) behavior (March and Simon 1958; Kahneman, Slovic and Tversky 1982). Indeed, while people can 
hold many beliefs about any given behavior, they can attend to only a relatively small number at any given moment. The present study suggests that these beliefs result from the disconfirmation of outcome expectations (i.e., the appreciation of previous performance), structural and strategic inertia, and perceived internal and market inhibitors. This limited set of subjective antecedents is in line with decision-making theory, which expects managers to decide on the basis of subjective, past-oriented and simple data inputs (Janis and Mann 1977; Krabuanrat and Phelps 1998; Eisenhardt and Zbaracki 1992).

While ongoing internationalization seems not to be the result of extended decisionmaking, it is neither a purely evolutionary process as assumed in the Uppsala Model (Johanson and Vahlne 1990). A firm's attitude towards internationalization as well as the interpretation of exogenous factors steer a firm's propensity to ongoing internationalization. Therefore, we suggest embedding an attitudinal component in the U-Model. A conceptual split between instrumental and attitudinal commitment in the internationalization process theory assures conceptual congruence with theories of planned behavior and allows for a more dynamic perspective on, for instance, discontinuity and acceleration in the internationalization process of the firm. In sum, ongoing internationalization is to be considered and modeled as a semi-volitional process.

Further analysis is required to better understand the interaction between the volitional and non-volitional antecedents of the propensity to continue internationalization. Moreover, the model would significantly benefit from an optimization of some of the measures. The moderating inhibitors that impact upon the relationship between the normative constructs (intensity and strategic fit) and propensity require additional investigation as well as a broader operationalization. Further, the current model misses the possible mediating role of risk 
propensity and risk perception (Forlani and Mullins 2000) as critical drivers in many heuristic and decision-making models (Sitkin and Weingart 1995). Finally, the external validity of this perspective has to be enhanced be focusing on other and more specific industry contexts. 


\section{References}

Ajzen, I. (1988) Attitudes, Personality and Behavior, Chicago: Dorsey Press.

Ajzen, I. (1991) 'The Theory of Planned Behavior', Organizational Behavior and Human Decision Processes, 50: 179-211.

Ajzen, I. and Fishbein, M. (1980) Understanding Attitudes and Predicting Social Behavior, Englewood Cliffs, NJ: Prentice-Hall.

Anderson, E. and Weitz, B. (1992) 'The Use of Pledges to Build and Sustain Commitment in Distribution Channels' Journal of Marketing Research, 29: 18-34.

Andersen, O. (1993) 'On the Internationalization Process of the Firm: A Critical Analysis' Journal of International Business Studies, 24(2): 209-231.

Anderson, R.E. (1973) 'The Effect of Disconfirmed Expectancy on Perceived Product Performance' Journal of Marketing Research, 10: 38-44

Armstrong, J.S. and Overton, T.S. (1977) 'Estimating Non-Response Bias in Mail Surveys' Journal of Marketing Research, 14: 396-402.

Bandura, A. (1991) 'Social-Cognitive Theory of Self-Regulation' Organizational Behavior and Human Decision Processes, 50: 258-287.

Barclay, D., Higgins, C. and Thompson, R. (1995) 'The Partial Least Squares Approach to Causal Modeling: Personal Computer Adoption and Use as Illustration' Technology Studies, 2(2): 285-309.

Bell, J. (1995) 'The Internationalization of Small Computer Software Firms: A Further Challenge to 'Stage' Theories' European Journal of Marketing, 29(8): 60-75.

Benito, G.R.G. and Welch, L.S. (1997) 'De-internationalization' Management International Review, 2(Special Issue): 7-25. 
Björkman, I. and Kock, S. (1997) 'Inward International Activities in Service Firms Illustrated by Three Cases From the Tourism Industry' International Journal of Service Industry Management, 8(5): 362-376.

Björkman, I. and Forsgren, M. (2000) 'Nordic International Business Research A review of its Development' International Studies of Management and Organization, 30(1): 6-25.

Blomstermo, A. and Sharma, D.D. (2003) Learning in the Internationalization Process of Firms, Cheltenham, UK: Edwar Elgar.

Boeker, W. (1989) 'The Development and Institutionalization of Subunit Power in Organizations' Administrative Science Quarterly, 34: 388-410.

Brown, S.W., Van Bennekom, F., Goffin, K, Hahn, A. and Alexander J.A. (2001) S-Business: Defining the Services Industry, Fort Myers, FL: AFSM International.

Buckley, P.J. (1996) 'The Role of Management in International Business Theory: A MetaAnalysis and Integration of the Literature on International Business and International Management' Management International Review, 36(1 Special Issue): 7-54.

Buckley, P.J., Pass, C.L. and Prescott, K. (1991) 'The Internationalization of Service Firms: A Comparison with the Manufacturing Sector' Scandinavian International Business Review, 1(1): 39-56.

Capar, N. and Kotabe, M (2003) 'The Relationship between International Diversification and Performance in Service Firms.' Journal of International Business Studies, 34: 345-355.

Chin, W. (1998) 'The Partial Least Squares Approach to Structural Equation Modeling', in G.A. Marcoulides (ed.) Modern Business Research Methods, Mahwah, NJ: Lawrence Erlbaum Associates, pp. 295-336.

Chin, W. (2000) 'Frequently Asked Questions - Partial Least Squares \& PLS-Graph', [www document]. http://disc-nt.cba.uh.edu/chin/plsfaq.htm (accessed 1 June 2003). 
Chin, W. (2001) PLS-Graph User's Guide Version 3.0, Houston, TX: C.T. Bauer College of Business, University of Houston.

Coviello, N. and Munro, H. (1997) 'Network Relationships and the Internationalization Process of Small Software Firms’ International Business Review, 6(4): 361-386.

Cyert, R.M. and March, J.G. (1963) A Behavioral Theory of the Firm, Englewood Cliffs, NJ: Prentice Hall.

Davis, F.D., Bagozzi, R.P., and Warshaw, P.R. (1989) 'User Acceptance of Computer Technology: A Comparison of Two Theoretical Models' Management Science, 35(8): 982-1003.

Douglas, Susan P. and Craig, C.S. (1996) 'Executive Insights: Global Portfolio Planning and Market Interconnectedness' Journal of International Marketing, 4(1): 93-110.

Dretske, F. (2000) Perception, Knowledge and Belief, Cambridge, UK: Cambridge University Press.

Duxbury, L.E. and Higgins, C.A. (1991) 'Gender Differences in Work-Family Conflict' Journal of Applied Psychology, 76(1): 60-74.

Eisenhardt, K.M. and Zbaracki, M.J. (1992) 'Strategic Decision Making' Strategic Management Journal, 13: 17-37.

Ekeledo, I. and Sivakumar, K. (1998) 'Foreign Entry Mode Choice of Service Firms: A Contingency Perspective' Journal of the Academy of Marketing Science, 26: 274-292.

Ellis, P. and Pecotich, A. (2001) 'Social Factors Influencing Export Initiation in Small and Medium-sized Enterprises' Journal of Marketing Research, 38: 119-130.

Eriksson, K., Johanson, J., Majkgård, A. and Sharma, D.D. (1997) 'Experiential Knowledge and Cost in the Internationalization Process' Journal of International Business Studies, 28(second quarter): 337-360. 
Eriksson, K., Johanson, J., Majkgård, A. and Sharma, D.D. (2000) 'Effect of Variation on Knowledge Accumulation in the Internationalization Process' International Studies of Management and Organization, 30(1): 26-44.

Erramilli, M.K. (1990) 'Entry Mode Choice in Service Industries' International Marketing Review, 5(7): 50-62.

Erramilli, M.K. (1992) 'Influence of Some External and Internal Environmental Factors on Entry-Mode Choice in Service Firms' Journal of Business Research, 25(4): 263-276.

Fishbein, M. and Ajzen, I. (1975) Belief, Attitude, Intention, and Behavior: An Introduction to Theory and Research, Reading, MA: Addison-Wesley.

Forlani, D. and Mullins, J.W. (2000) 'Percieved Risks and Choices in Enterpreneurs' New Venture Decisions' Journal of Business Venturing, 15: 305-322.

Fornell, C. and Larcker, D.F. (1981) 'Evaluating Structural Equation Models with Unobservable Variables and Measurement Error' Journal of Marketing Research, 18: 39-50.

Forsgren, M. (2002) 'The Concept of Learning in the Uppsala Internationalization Process Model: A Critical Review' International Business Review, 11: 257-277.

Grönroos, G. (1990). Service Management and Marketing. Managing the Moments of Truth in Service Competition, Lexington, MA: Lexington Books.

Gundlach, G.T., Achrol, R.S. and Mentzer, J.T. (1995) 'The Structure of Commitment in Exchange' Journal of Marketing, 59(January): 78-92.

Hadjikhani, A. (1997) 'A Note on the Criticisms against the Internationalization Process Model’ Management International Review, 37(2 Special Issue): 43-66.

Hamel, G. and Prahalad, C.K. (1989) 'Strategic Intent' Harvard Business Review, 67(3): 6376. 
Huber, G.P. (1991) 'Organizational Learning: The Contributing Processes and the Literatures. Organization Science, 2(1):88-115.

Hulland, J. (1999) 'Use of Partial Least Squares (PLS) in Strategic Management Research: A Review of Four Recent Studies'Strategic Management Journal, 20: 195-204.

Janis, I.L. and Mann, L. (1977) Decision Making: A Psychological Analysis of Conflict, Choice and Commitment, New York: The Free Press.

Johanson, J. and Vahlne, J.-E. (1977) 'The Internationalization Process of the Firm - A Model of Knowledge Development and Increasing Foreign Market Commitment' Journal of International Business Studies, .8(1): 23-32.

Johanson, J. and Vahlne, J.-E. (1990) 'The Mechanism of Internationalization' International Marketing Review, 7(4): 11-24.

Jöreskog, K.G. and Wold, H. (1982) 'The ML and PLS Techniques For Modeling with Latent Variables: Historical and Comparative Aspects' in H. Wold and K. Jöreskog (eds.), Systems Under Indirect Observation: Causality, Structure, Prediction, (Vol. I) Amsterdam: North-Holland, pp.263-270.

Kahneman, D., Slovic, P. and Tversky, A. (1982) Judgement under Uncertainty: Heuristics and Biases, Cambridge, UK: Cambridge University Press.

Kelly, D. and Amburgey, T.L. (1991) 'Organizational Inertia and Momentum: A Dynamic Model of Strategic Change' Academy of Management Journal, 34(3): 591-612.

Kim, D. (2003) 'The Internationalization of US Internet Portals: Does it Fit the Process Model of Internationalization?' Marketing Intelligence \& Planning, 21(1): 23-36.

Knight, G. (1999) 'International Services Marketing: Review of Research, 1980-1998' Journal of Services Marketing, 13 (4/5): 347-360.

Krabuanrat, K. and Phelps, R. (1998) 'Heuristics and Rationality in Strategic Decision Making: An Exploratory Study' Journal of Business Research, 41: 83-93. 
Kundu, S.K. and F. Contractor (1999) 'Country Location Choices of Service Multinationals: An Empirical Study of the International Hotel Sector' Journal of International Management, 5: 299-317.

La, V., P. Patterson, C. Styles and K. Prasongsakarn (2002), 'The Pivotal Role of Personnel in the Export Performance of Professional Services - A Qualitative Study' in R. Shaw, S. Adam and H. McDonald (eds.), Proceedings of Australian and New Zealand Marketing Educators Conference, Melbourne: ANZMAC.

Lages, L.F. and Montgomery, D.B. (2001) 'The Effects of Prior Export Performance on Firms' Commitment to Exporting and Marketing Strategy Adaptation to the Foreign Market: Evidence from Small and Medium-sized Exporters' Research Paper 1701, Research Paper Series, Graduate School of Business, Stanford University.

Li, J. (1994) 'Experience Effects and International Expansion: Strategies of Service MNCs in the Asia-Pacific Region' Management International Review, 34(3): 217-234.

Lommelen, T., Matthyssens, P. and Pauwels, P. (2001) 'The Internationalization of Services: Riding on the Waves' Competitive Paper presented at the 27th Annual Meeting of the European International Business Academy (EIBA), Paris, France.

Lovelock, C.H. and Yip, G.S. (1996) 'Developing Global Strategies for Service Businesses' California Management Review, 38(2): 64-86.

Lohmöller, J.-B. (1989) Latent Variable Path Modeling with Partial Least Squares, Heidelberg, Germany: Physica-Verlag.

Majkgård, A. and Sharma, D.D. (1998) 'Client-Following and Market-Seeking in the Internationalization of Service Firms' Journal of Business-to-Business Marketing, 4(3): $1-40$.

March, J.G. and Simon, H.A. (1958) Organizations, New York, NJ: John Wiley. 
McLaughlin, C.P. and Fitzsimmons, J.A. (1996) 'Strategies for Globalizing Service Operations' International Journal of Service Industry Management, 7(4): 43-57.

Meyer, J.P. and Allen, N.J. (1991) 'A Three Component Conceptualization of Organizational Commitment' Human Resource Management Review, 1(1): 61-89.

Millington, A.I. and Bayliss, B.T. (1990) 'The Process of Internationalization: UK Companies in the EC' Management International Review, 30(1): 151-161.

Mowday, R.T., Porter, L.W. and Steers, R.M. (1982) Employee-Organization Linkages: The Psychology of Commitment, Absenteeism, and Turnover, New York: Academic Press.

Nelson, R.R. and Winter, S.G. (1982) An Evolutionary Theory of Economic Change, The Belknap Press of Harvard University Press: Cambridge, MA.

O'Farrell, P.N., Wood, P.A. and Zheng J. (1996) 'Internationalization of Business Services: An Interregional Analysis’ Regional Studies, 30(2): 101-118.

Oliver, R.L. (1980) 'A Cognitive Model of the Antecedents and Consequences of Satisfaction Decisions' Journal of Marketing Research, 17: 460-469.

Oliver, R.L. and DeSarbo, W.S. (1988) 'Response Determinants in Satisfaction Judgments' Journal of Consumer Research, 14: 495-508.

Patterson, P.G. and M. Cicic (1995), 'A Typology of Service Firms in International Markets: an Empirical Investigation', Journal of International Marketing 3(4): 57-83.

Patterson, P.G., de Ruyter, K. and Wetzels, M. (1999) 'Modelling Firms Propensity to Continue Service Exporting: A Cross-Country Analysis' International Business Review, 8: $351-365$.

Patterson, P.G., Cicic, M. and Shoham, A. (1997) 'A Temporal Sequence Model of Satisfaction and Export Intentions of Service Firms' Journal of Global Marketing, 10(4): $23-43$. 
Pauwels, P. and Matthyssens, P. (2003) 'The Dynamics of International Market Withdrawal' In S. Jain (ed.) State of the Art of Research in International Marketing, Edward Elgar Publishing: Cheltenham, UK, in Press.

Pedersen, T. and Petersen, B. (1998) 'Explaining Gradually Increasing Resource Commitment to a Foreing Market' International Business Review, 7: 483-501.

Penrose, E. (1959) The Theory of Growth of the Firm, New York: John Wiley \& Sons.

Ross, J. and Staw, B.M. (1993) 'Organizational Escalation and Exit: Lessons from the Shoreham Nuclear Power Plant' Academy of Management Journal, 36(4): 701-732.

Sheppard, B.H., Hartwick, J. and Warshaw, P.R. (1988) 'The Theory of Reasoned Action: A Meta-Analysis of Past Research with Recommendations for Modifications and Future Research’ Journal of Consumer Research, 15: 325-343.

Sitkin, S.B. and Weingart, L.R. (1995) 'Determinants of Risky Decision-Making Behavior: A Test of the Mediating Role of Risk Perceptions and Propensity'Academy of Management Journal, 38(6): 1573-1592.

Skarmeas, D., Katsikeas, C.S. and Schlegelmilch, B.B. (2002) 'Drivers of Commitment and its Impact on Performance in Cross-Cultural Buyer-Seller Relationships: The Importer's Perspective' Journal of International Business Studies, 33(4): 757-783.

Selznick, P. (1957) Leadership in Administration, Evanston, IL: Row, Peterson.

Sullivan, D. (1994) 'Measuring the Degree of Internationalization of a Firm' Journal of International Business Studies, 25 (Second Quarter): 325-342.

Sullivan, D. and Bauerschmidt, A. (1990) 'Incremental International Integration: A Test of Johanson and Vahlne's Thesis' Management International Review, 30(1): 19-30.

Turnbull, P.W. (1987) 'A Challenge to the Stages Theory of the Internationalization Process' In S.D. Reid and P.J. Rosson (eds.) Managing Export Entry and Expansion, NY: Praeger, pp. 21-40. 
Wang, G. and Olsen, J.E. (2002) 'Knowledge, Performance, and Exporter Satisfaction: An Exploratory Study’ Journal of Global Marketing, 15(3/4): 39-64.

Werts, C.E., Linn, R.L. and Jöreskog, K.G. (1974) 'Intraclaa Reliability Estimates: Testing Structural Assumptions' Educational and Psychological Measurement, 34: 25-33.

Winsted, K.F. and Patterson, P.G. (1998) 'Internationalization of Services: The Service Exporting Decision' Journal of Services Marketing, 12(4): 294-311.

World Trade Organization (2001) GATS - Facts and Fiction, World Trade Organization.

Young, S, Hamill J., Wheeler C. and Davis, J.R. (1989) International Market Entry and Development Strategies and Management, Prentice Hall: Englewood Cliffs, NJ.

Zeithaml, V.A. and Bittner, M.J. (1996) Services Marketing, McGraw Hill: New York. 
Figure 1: The propensity to continue service internationalization:

A partially mediated model of planned behavior

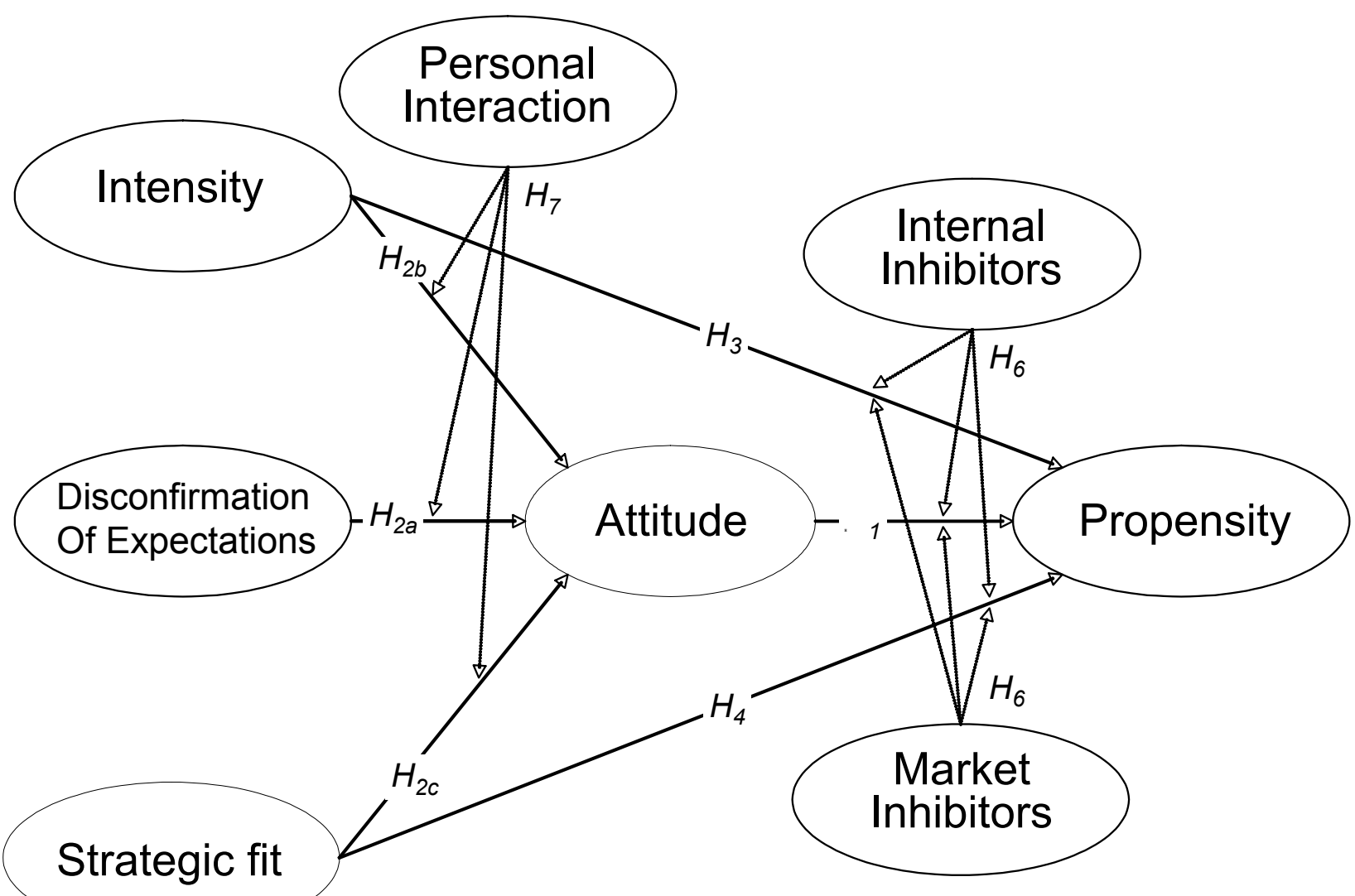


Figure 2: PLS parameters estimates of partially mediated model

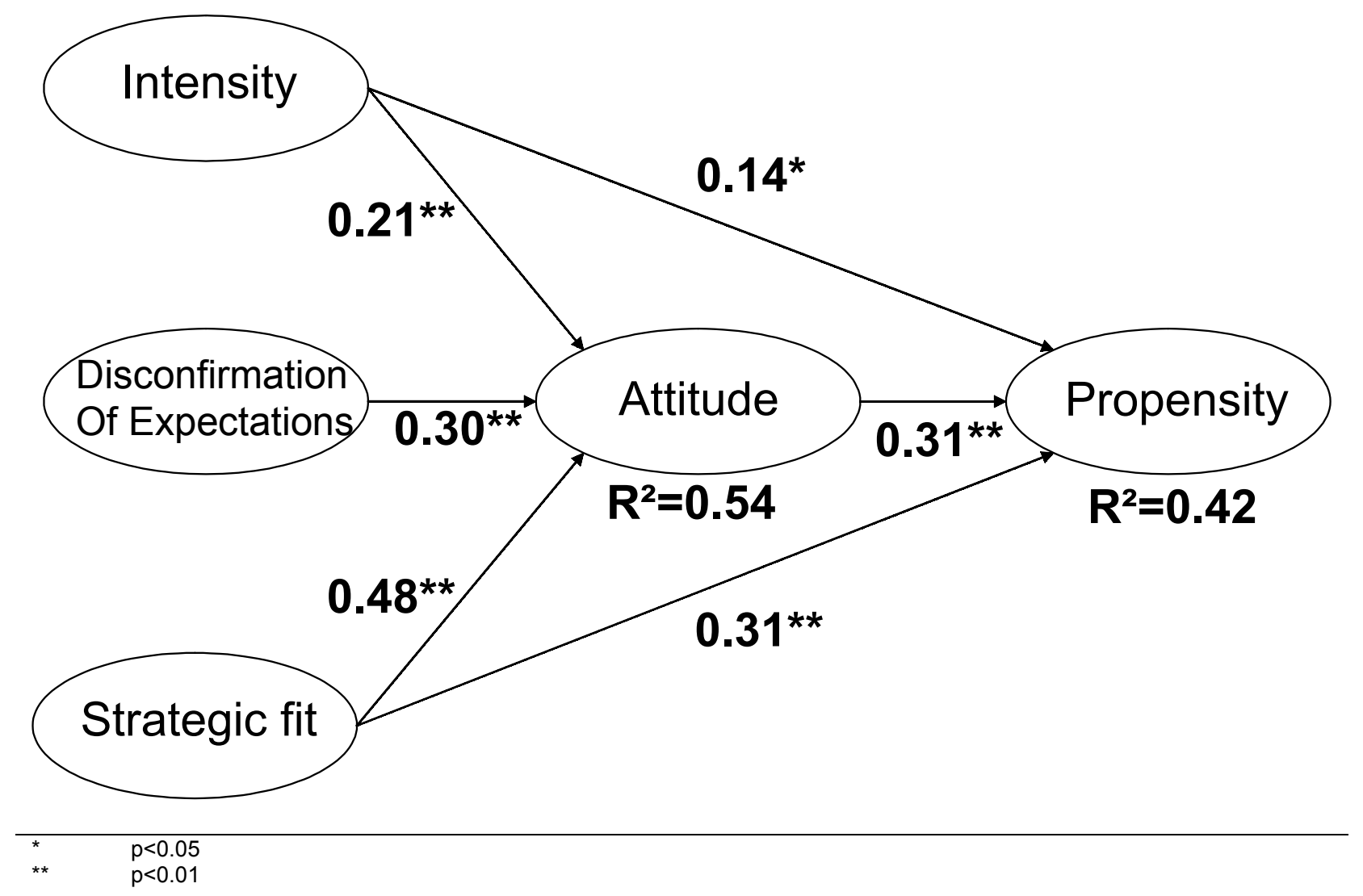


Table 1: Measures

\begin{tabular}{|c|c|c|}
\hline Label (type) & Indicators & Anchor Points \\
\hline $\begin{array}{l}\text { Intensity } \\
\text { (Open) }\end{array}$ & $\begin{array}{l}-\% \text { of annual sales from internat. operations } \\
\text { most recent fiscal year } \\
\text { - \% of annual sales from internat. operations } \\
\text { past three financial years }\end{array}$ & $\mathrm{N} / \mathrm{a}$ \\
\hline $\begin{array}{l}\text { Disconfirmation } \\
\text { Of Expectations } \\
\text { (5-point Likert type) }\end{array}$ & $\begin{array}{l}\text { - overall performance rel. to expectations } \\
\text { - accrued benefits rel. to expectations } \\
\text { - problems rel. to expectation }\end{array}$ & much worse/much better \\
\hline $\begin{array}{l}\text { Strategic Fit } \\
\text { (5-point Likert type) }\end{array}$ & $\begin{array}{l}\text { - internationalization is consistent with our } \\
\text { organization's mission } \\
\text { - The financial returns are greater if we } \\
\text { internationalize } \\
\text { - international operations are potentially } \\
\text { more profitable than domestic operations } \\
\text { - internationalization enhances services } \\
\text { diversification } \\
\text { - internationalization helps developing } \\
\text { competitive services }\end{array}$ & $\begin{array}{l}\text { strongly disagree/ } \\
\text { strongly agree }\end{array}$ \\
\hline $\begin{array}{l}\text { Attitude } \\
\text { (5-point Likert type) }\end{array}$ & $\begin{array}{l}\text { - commitment to internationalization is high } \\
\text { - internationalization is a desirable path } \\
\text { - internationalization can make major } \\
\text { contribution to the firm's growth }\end{array}$ & $\begin{array}{l}\text { strongly disagree/ } \\
\text { strongly agree }\end{array}$ \\
\hline $\begin{array}{l}\text { Personal Interaction } \\
\text { (5-point Likert type) }\end{array}$ & $\begin{array}{l}\text { - overall interaction } \\
\text { - face-to-face interaction } \\
\text { - frequency of interaction }\end{array}$ & high/low \\
\hline $\begin{array}{l}\text { Internal inhibitors } \\
\text { (5-point Likert type) }\end{array}$ & $\begin{array}{l}\text { - lack of expertise } \\
\text { - inappropriate services } \\
\text { - inadequate resources } \\
\text { - lack of capital }\end{array}$ & hinder to great extent/ \\
\hline $\begin{array}{l}\text { Market } \\
\text { Inhibitors } \\
\text { (5-point Likert type) }\end{array}$ & $\begin{array}{l}\text { - difficulty of gaining entry } \\
\text { - lack of contacts } \\
\text { - underdeveloped markets } \\
\text { - competition abroad }\end{array}$ & not hindering at al \\
\hline $\begin{array}{l}\text { Propensity } \\
\text { (5-point Likert type) }\end{array}$ & $\begin{array}{l}\text { - likelihood of continuing internationalization } \\
\text { - possibility of continuing internationalization } \\
\text { - chance of continuing internationalization }\end{array}$ & very unlikely/very likely \\
\hline
\end{tabular}


Table 2: Composite reliability and intercorrelations of latent variables \# of Composite Intercorrelations of Latent Variables items Reliability

$\begin{array}{llll}1 . & 2 . & 3 . & 4 .\end{array}$

4.

5.

\begin{tabular}{|c|c|c|c|c|c|c|c|}
\hline 1. Intensity & 2 & 0.92 & 0.92 & & & & \\
\hline 2. Disconfirm. & 3 & 0.91 & 0.24 & 0.88 & & & \\
\hline 3. Strategic Fit & 5 & 0.90 & 0.40 & 0.22 & 0.79 & & \\
\hline 4. Attitude & 3 & 0.91 & 0.49 & 0.45 & 0.63 & 0.85 & \\
\hline 5. Propensity & 3 & 0.96 & 0.38 & 0.26 & 0.57 & 0.59 & 0.95 \\
\hline
\end{tabular}




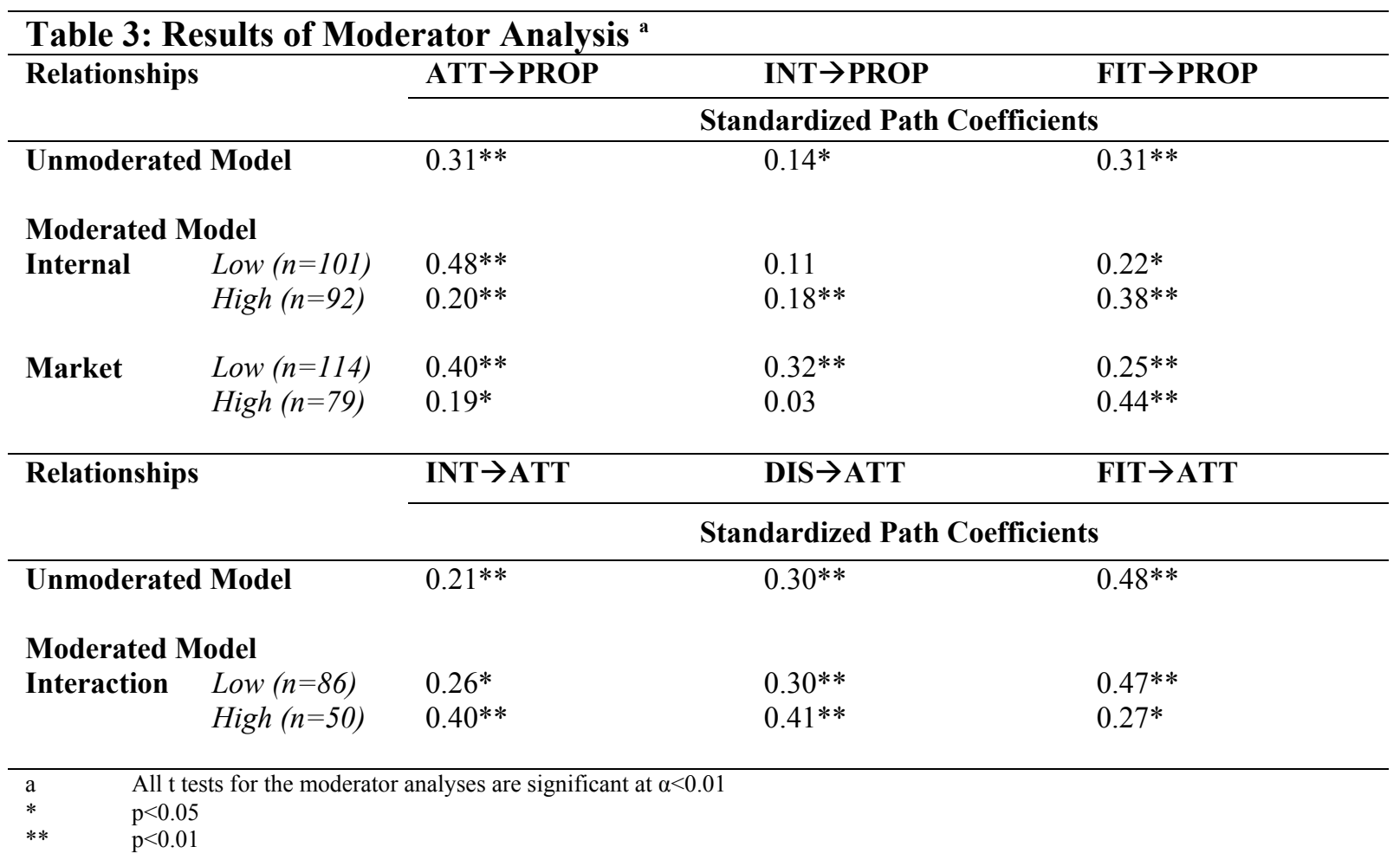

